Kajian Jurnalisme

Volume 05 Nomor 02 Tahun 2022

DOI: $10.24198 /$ jkj.v5i2.32802

\title{
Kepuasan Khalayak dalam Mendengarkan Insert Berita The Highlights Radio Prambors Jakarta
}

\author{
Wicaksono Tri Kurniawan, Henny Sri Mulyani, dan Muhammad Zen Al-Faqih \\ Fakultas Ilmu Komunikasi, Universitas Padjadjaran \\ wicaksonotk@gmail.com
}

\begin{abstract}
In the midst of technology development, the growth of radio listeners continues to rise. Jakarta has become the city with the highest growth in radio listeners in the past year. In addition to prioritizing entertainment broadcasts, radio in Jakarta is starting to consistently work on journalistic broadcasts in the form of flash news insertion. Among dozens of stations in Jakarta, there are eight major radio stations that regularly broadcast flash news. One of them is Prambors, where The Highlights insert broadcast on two prime time programs and disseminated its broadcast to eight cities. This study aims to find out the satisfaction of Sunset Trip program listeners on Prambors Jakarta after listening to The Highlights based on Dennis McQuails's four motives of media consumption: information, personal identity, satisfaction integration and social interaction, and entertainment. This study uses descriptive quantitative methods and uses and gratifications theory with Phillip Palmgreen's concept, Gratifications Sought and Gratifications Obtained. Researchers distributed questionnaires to 100 respondents who are Sunset Trip listeners aged 15-29 years domiciled in DKI Jakarta and surrounding areas. The results showed information and entertainment motives are two of the biggest motives that listeners have in listening to The Highlights. However, of the four motives none of the motives can be satisfied. The results of the measurement of satisfaction by mean comparison of Gratifications Sought and Gratifications Obtained scores showed that the listener was insatiable after listening to The Highlights.
\end{abstract}

Keywords: motives; satisfaction; gratifications sought; gratifications obtained; The Highlights

\begin{abstract}
Abstrak
Di tengah gempuran perkembangan teknologi, radio tetap mengalami pertumbuhan pendengar. Di Indonesia, Jakarta menjadi kota dengan pertumbuhan pendengar paling tinggi dalam satu tahun terakhir. Selain mengutamakan siaran hiburan, radio di Jakarta kini mulai konsisten menggarap siaran jurnalistik berupa kilas berita dalam bentuk insert. Di antara puluhan stasiun radio di Jakarta, ada delapan radio besar yang rutin menyiarkan kilas berita. Salah satunya Prambors, di mana insert kilas beritanya, The Highlights yang disiarkan di dua program prime time disebarluaskan siarannya ke delapan kota jaringan Prambors. Penelitian ini bertujuan untuk mengetahui kepuasan pendengar program Sunset Trip di Radio Prambors Jakarta setelah mendengarkan The Highlights berdasarkan empat motif pengonsumsian media menurut Dennis McQuail, yakni motif informasi, identitas pribadi, kepuasan integrasi dan interaksi sosial, dan hiburan. Penelitian ini menggunakan metode kuantitatif deskriptif dan teori Uses and Gratifications dengan turunan konsep Gratifications Sought dan Gratifications Obtained menurut Philip Palmgreen. Teknik pengumpulan data dilakukan dengan menyebarkan kuesioner kepada 100 responden yang merupakan pendengar Sunset Trip berusia 15-29 tahun berdomisili di DKI Jakarta dan sekitarnya. Hasil penelitian menunjukkan dari keempat motif yang diteliti, motif informasi dan motif hiburan merupakan dua motif terbesar yang dimiliki pendengar dalam mendengarkan The Highlights. Namun, dari keempat motif tidak ada satupun motif yang dapat terpuaskan. Hasil pengukuran tingkat kepuasan berupa perbandingan mean skor Gratifications Sought dan Gratifications Obtained menunjukkan pendengar tidak terpuaskan setelah mendengarkan The Highlights.
\end{abstract}

Kata kunci: motif; kepuasan; gratifications sought; gratifications obtained; The Highlights

Korespondensi: Wicaksono Tri Kurniawan, S.I.Kom., Fakultas Ilmu Komunikasi Universitas Padjadjaran, J1. Raya Bandung Sumedang KM 21, Kec. Jatinangor, Kabupaten Sumedang, Jawa Barat, 45363, Email: wicaksonotk@gmail.com

Menyerahkan: Maret 2021, Diterima: Oktober 2021, Terbit: Januari 2022

ISSN: 2549-0559 (cetak), ISSN: 2549-1946 (online), Website: http://jurnal.unpad.ac.id/kajian-jurnalisme 
130 | Kajian Jurnalisme

Volume 05 Nomor 02 Tahun 2022

DOI: $10.24198 / j \mathrm{kj} . v 5 \mathrm{i} 2.32802$

\section{PENDAHULUAN}

Satu tahun awal pandemi yang terjadi di Indonesia berpengaruh baik terhadap peningkatan pendengar radio, yang pada akhirnya membuat tren penetrasi pendengar radio kembali meningkat. Menurut survei dari Fieldwork yang dilakukan pada April hingga Juni 2020, total pendengar radio di 10 kota di Indonesia mengalami peningkatan lebih dari satu juta pendengar dibandingkan sebelum terjadinya pandemi (PRSSNI, 2020).

Fenomena yang terjadi saat ini adalah pendengar radio didominasi oleh generasi milenial dan generasi Z. Berdasarkan survei terakhir yang dilakukan Nielsen Radio Audience Measurement pada 2016, menunjukkan 57 persen dari total pendengar radio berasal dari generasi Z (10-14 tahun) dan milenial (15-34 tahun). Lebih spesifik lagi, 57 persen itu terbagi dari milenial sebanyak 38 persen dan generasi $Z$ sebanyak 28 persen. Hal ini mematahkan asumsi yang muncul radio hanya didengarkan oleh generasi usia yang lebih berumur ketimbang generasi usia muda (Siradj \& Hidayat, 2018).

Secara nasional, 57 persen dari total jumlah pendengar radio di Indonesia berasal dari kedua generasi tersebut. Sementara di Jakarta, ada lebih dari 9 juta orang yang mendengarkan radio secara streaming melalui gawai, di mana mayoritas pendengar berasal dari usia 25 sampai 34 tahun (Syukro, 2019). Perkembangan teknologi dan digital yang masif telah memengaruhi perilaku khalayak dalam mengakses radio. Kedua generasi ini merupakan generasi yang melek dan dekat dengan teknologi, sehingga kemajuan teknologi dapat memudahkan dua generasi tersebut untuk mengakses radio secara digital.

Data tersebut tentu menjadi potensi yang tinggi bagi perkembangan radio khususnya di Jakarta. Hal ini juga membuat para pelaku radio di Jakarta semakin berlomba-lomba dalam menyajikan siaran yang berkualitas, tidak hanya dari segi hiburan, melainkan juga dari sisi informasi atau jurnalistik. Informasi berupa berita merupakan salah satu elemen penting bagi radio siaran, terlepas dari format apa yang digunakan setiap stasiun radio.

Saat ini, stasiun-stasiun radio besar di Jakarta mulai fokus dan konsisten untuk menyajikan siaran jurnalistik dalam bentuk kilas berita berupa insertion, yakni suatu segmen yang disisipkan dalam suatu program tertentu. Hal tersebut menjadi fenomena baru di dunia radio di Jakarta khususnya dalam hal konten jurnalistik radio di Jakarta. Berdasar pengamatan peneliti, ada delapan stasiun radio besar di Jakarta yang konsisten dalam menyiarkan siaran jurnalistik dalam bentuk insert kilas berita, yakni Prambors, Mustang, Jak FM, Gen FM, Trax FM, Most Radio, Kis FM, dan Elshinta.

Sejak kemunculan era reformasi, jurnalistik radio di Indonesia mengalami perkembangan secara pesat. Berbagai stasiun radio swasta berlomba-lomba untuk menyajikan siaran warta beritanya secara mandiri. Jika dilihat dari nilai aktualitas berita, radio siaran memang merupakan media massa yang paling aktual (Ardianto, Komala, \& Karlinah, 2014).

Jurnalistik radio memiliki kekuatan dibandingkan dengan jurnalistik pada media massa lain. Penyampaian pesan melalui radio bersifat ketersegeraan (actuality), lebih simpel dan cepat dari pada televisi atau media cetak. Format kemasan dan lokalitas juga menjadi alasan jurnalistik radio tidak ditinggalkan pendengarnya. Hal inilah yang melahirkan prinsip berita di radio siaran, yakni berita detik ini diperdengarkan detik ini juga. Berita radio merupakan apa yang terjadi saat ini, apa yang segera terjadi, dan apa yang akan terjadi. Berita radio merupakan laporan tentang peristiwa, opini, situasi kondisi, interpretasi yang penting dan menarik, masih baru, dan harus sesegera mungkin diperdengarkan. Format lokalitas akan sangat memengaruhi efektif tidaknya suatu berita radio. Efektivitas berita sangat tergantung pada aspek lokalitas dengan pendengar, baik itu secara geografis, emosional, serta psikologis (Setyowati, Sudaryanto, \& Satvikadewi, 2015). 
Perkembangan jurnalistik radio di Indonesia juga sejalan dengan peningkatan jumlah stasiun radio baru yang muncul di Indonesia. Dari tahun ke tahun, stasiun radio baru terus bertambah. Data terakhir yang tercatat di Kementerian Komunikasi dan Informatika, pada 2016 terdapat kurang lebih 2.845 lembaga penyiaran radio di Indonesia. Jumlah tersebut mengalami peningkatan yang drastis jika dibandingkan pada era reformasi yakni 1998 di mana jumlah stasiun radio hanya kurang dari 1.000 lembaga (Kementerian Komunikasi dan Informatika, 2016).

Namun, peningkatan drastis lembaga radio di Indonesia tidak diikuti dengan peningkatan dari segi penetrasi atau jumlah pendengar radio secara nasional. Berdasar Survei Nielsen Consumer Media View pada tahun 2017, penetrasi radio masih menempati urutan keempat dibanding jenis media lain. Radio hanya memiliki penetrasi sebesar 37 persen, jauh tertinggal dari televisi sebanyak 96 persen, media luar ruang dengan 53 persen, dan internet sebesar 44 persen (Komisi Penyiaran Indonesia, 2018). Data tersebut menunjukkan radio masih kalah pamor dari media lain seperti televisi dan media digital. Khalayak tidak menjadikan radio sebagai pilihan utamanya dalam pengonsumsian media.

Hal ini pun dikuatkan dengan data dari Badan Pusat Statistik (BPS). Berdasarkan survei BPS pada 2018, masyarakat usia 10 tahun ke atas yang mendengarkan radio dalam seminggu terakhir hanya 13,31 persen jika diakumulasikan secara nasional (Kusnandar, 2019). Pesatnya perkembangan teknologi membuat gaya hidup masyarakat mengalami pergeseran, di mana radio perlahan-lahan mulai tergusur dengan media digital yang terus berkembang.

Namun, pendengar radio di Jakarta nyatanya terus mengalami pertumbuhan. Jakarta merupakan kota dengan pertumbuhan pendengar radio yang signifikan di Indonesia. Pada 2019, Data RAM Nielsen Kuartal III 2019 mencatat jumlah pendengar radio di Jakarta lebih dari 11 juta orang, naik lebih dari tiga juta pendengar dari tahun sebelumnya. Jumlah kependengaran radio di Jakarta selama pandemi pun mengalami peningkatan. Pada periode April hingga Juni 2020, Jakarta mengalami kenaikan lebih dari 500 ribu pendengar radio. Hal ini menunjukkan bahwa radio masih menjadi media yang banyak dicari oleh masyarakat Jakarta. Radio masih menjadi salah satu pilihan utama masyarakat Jakarta untuk mendapatkan informasi dan hiburan.

Dari kedelapan stasiun radio yang menyiarkan konten insertion jurnalistik, peneliti tertarik untuk meneliti kilas berita yang disiarkan pada Radio Prambors, yakni The Highlights. Selain memiliki segmentasi pendengar usia muda, Prambors menyiarkan The Highlights pada jam siaran prime time. Pada jam siaran tersebut, konten insert The Highlights tidak hanya disiarkan di Jakarta, melainkan juga direlai ke delapan kota jaringan Prambors di Indonesia, yakni Bandung, Makassar, Manado, Medan, Semarang, Surabaya, Yogyakarta, dan Solo. Hal inilah yang menjadi keunggulan siaran insert berita di Prambors dengan siaran insert berita yang dimiliki radio lainnya di Jakarta.

Sebagai salah satu radio tertua yang telah menerapkan segmentasi pendengar usia muda sejak awal didirikan pada 1951, Prambors merupakan radio yang telah dikenal baik oleh orang banyak dan memiliki nama besar tidak hanya di Jakarta melainkan di Indonesia. Pada awal 2021, Prambors mencatat pencapaian dengan menjadi radio yang paling banyak didengar di Indonesia. Berdasarkan data dari lembaga riset media Populix pada kuartal pertama 2021, jumlah pendengar Radio Prambors di seluruh Indonesia tercatat mencapai lebih dari dua juta pendengar, atau yang terbanyak di Indonesia (Media Indonesia, 2021).

The Highlights disiarkan pada dua program prime time yang diudarakan pada Senin sampai Jumat, yakni Desta Gina In The Morning (06.00 s.d. 10.00 WIB) dan Sunset Trip (16.00 s.d. 20.00 WIB). Dua program prime time ini merupakan program unggulan yang dimiliki 


\section{2 | Kajian Jurnalisme}

Volume 05 Nomor 02 Tahun 2022

DOI: $10.24198 /$ jkj.v5i2.32802

Prambors Jakarta dan disiarkan ke jaringan-jaringan Prambors di kota lainnya. The Highlights yang disiarkan di program Desta Gina In The Morning dengan program Sunset Trip sendiri memiliki perbedaan. The Highlights yang disiarkan pada jam program Sunset Trip jumlah berita dan panjang kalimat berita yang disiarkan lebih banyak dan lebih detail ketimbang The Highlights pada jam program Desta Gina In The Morning.

Media massa digunakan oleh khalayak untuk mendapatkan kepuasan atas kebutuhannya. Khalayak dianggap secara aktif menggunakan media untuk memenuhi kebutuhannya. Dalam teori Uses and Gratification yang dikemukakan oleh Philip Palmgreen, khalayak mengonsumsi media tertentu atas motif tertentu dan memiliki hak penuh dalam memilih media mana yang akan dikonsumsinya (Christina, 2013).

Dalam teori Uses and Gratifications, terdapat salah satu konsep yang dikembangkan oleh Palmgreen, yakni Gratifications Sought dan Gratifications Obtained. Kebanyakan riset Uses and Gratifications memiliki fokus pada motif sebagai variabel independen seseorang yang memengaruhi penggunaan suatu media. Namun, Palmgreen juga kemudian menitikberatkan pada satu pertanyaan, yakni apakah khalayak dapat memperoleh kepuasan setelah mengonsumsi suatu media dari motif yang dimilikinya. Pengonsumsian media yang dilakukan oleh khalayak tersebut berangkat dari berbagai motif atau kebutuhan yang khalayak miliki, yang didasarkan pada kategori motif pengonsumsian media menurut Denis McQuail.

Menurut McQuail, ada empat motif yang mendasari khalayak dalam mendorong mereka mengonsumsi suatu media. Pertama, adalah motif informasi. Motif ini menyangkut kebutuhan akan informasi yang bisa memengaruhi atau membantu seseorang untuk menyelesaikan sesuatu. Kedua, motif identitas pribadi, yaitu harapan untuk dapat memperkuat dan menonjolkan sesuatu yang penting dalam kehidupan atau situasi khalayak. Ketiga, motif integrasi dan interaksi sosial, di mana khalayak mengonsumsi media untuk menjalin hubungan dan ikatan dengan orang sekitar. Keempat adalah motif hiburan, yakni kebutuhan khalayak akan rasa senang dan pemenuhan rasa emosional lainnya (Jati \& Herlina, 2013).

Peneliti pun membandingkan dua penelitian terdahulu yang sejenis dalam membahas konten berita di radio di Jakarta ataupun perilaku pendengarnya. Jurnal pertama berjudul "Model Penyiaran Dan Presentasi Siaran Berita Radio" oleh Rony Agustino Siahaan membandingkan model penyiaran satu radio berita dengan radio berita yang lain dengan meneliti empat radio berita di Jakarta, yakni KBR, Sindo Trijaya, Elshinta, dan Jak FM/Gen FM. Dari penelitian tersebut, terlihat bahwa siaran berita radio di Jakarta masih mengedepankan kecepatan dan kemendesakan serta mengutamakan hard news dan soft news sebagai konten utama mereka, namun dengan gaya pengemasan yang berbeda-beda menyesuaikan segmentasi pendengar dan format radionya. Misalnya, Jak FM dan Gen FM yang mengemas siaran berita mereka dengan cepat dan hanya selewat dalam format highlight news, mengingat segmentasi pendengar mereka adalah anak muda dan format siarannya adalah hiburan.

Kemudian, peneliti mengkaji jurnal berjudul "Survey Perilaku Mendengarkan Radio di Jakarta" oleh Siti Dewi Sri Ratna Sari dan Ervan Ismail. Jurnal ini memiliki relevansi mengenai data empirik terkait profil stasiun-stasiun radio dan pendengar yang ada di Jakarta serta penilaian pendengar terhadap isi siaran mereka. Dalam penelitannya, mereka menggunakan pendekatan kuantitatif berdasar teori Uses and Effects dengan metode survei deskriptif. Hasil penelitian menunjukkan mayoritas pendengar radio di Jakarta berasal dari usia 23 sampai 40 tahun, di mana Prambors menjadi radio segmen usia muda yang paling sering didengar di Jakarta. Jurnal tersebut juga menunjukkan acara berita atau informasi merupakan jenis acara kedua yang paling diminati.

Melihat dari kedua jurnal tersebut, peneliti berupaya mengambil kebaruan dengan 
membahas lebih dalam mengenai konten berita yang ada di suatu radio di Jakarta, yakni Prambors, serta menganalisis bagaimana perilaku serta kepuasan pendengarnya dalam merespon konen tersebut.

Hal-hal yang telah disebutkan di atas kemudian memunculkan pertanyaan dari peneliti, apakah pendengar program Sunset Trip di Radio Prambors Jakarta sudah terpuaskan dan terpenuhi kebutuhannya. Terlebih, konten berita dan informasi The Highlights di program Sunset Trip disajikan dengan lebih detail dan komprehensif. Maka dari itu, penelitian ini bertujuan untuk mengumpulkan data dan mendeskripsikan kepuasan yang diperoleh pendengar program Sunset Trip di Radio Prambors Jakarta berdasarkan motif informasi, identitas pribadi, integrasi dan interaksi sosial, dan hiburan.

\section{METODE}

Dalam penelitian ini, peneliti menggunakan penelitian kuantitatif, yakni metode penelitian yang dapat menggambarkan atau menjelaskan suatu masalah yang hasilnya dapat digeneralisasikan. Penelitian kuantitatif juga dapat membuat peneliti memahami suatu gejala secara lebih mendalam. Itu dikarenakan segala hal yang diteliti harus dapat diidentifikasi dan dikategorisasikan dengan jelas. Kemudian, hal yang telah diteliti dan diidentifikasikan tersebut diukur melalui cara-cara yang tepat (Pavitasari, Fadilah, \& Merdekawati, 2019). Selanjutnya, teori yang digunakan dalam penelitian ini adalah Uses and Gratifications dengan turunan konsep Gratifications Sought (motif yang dimiliki khalayak) dan Gratifications Obtained (kepuasan yang diperoleh dari motif khalayak) menurut Philip Palmgreen.

Untuk mengumpulkan data, peneliti menggunakan metode survei deskriptif. Survei deskriptif adalah metode riset di mana instrumen untuk mengumpulkan datanya menggunakan kuesioner. Metode ini bertujuan untuk memperoleh informasi tentang sejumlah responden yang dianggap mewakili populasi tertentu. Ketika menggunakan metode ini, proses pengumpulan dan analisis data bersifat sangat terstruktur dan mendetail (Gumilar \& Zulfan, 2014).

Dengan metode penelitian tersebut, peneliti ingin mengetahui bagaimana kepuasan pendengar program Sunset Trip di Radio Prambors Jakarta terhadap insert berita The Highlights dilihat dari motif-motif penggunaan media menurut Denis McQuail yang terdapat pada indikator penelitian dalam tabel operasionalisasi variabel.

Populasi yang digunakan dalam penelitian ini adalah total jumlah pendengar Radio Prambors Jakarta yang mendengarkan siaran program Sunset Trip. Pada jam siaran di program inilah insert berita The Highlights akan diteliti seberapa besar kepuasan pendengarnya oleh peneliti. Menurut data internal Radio Prambors yang peneliti himpun, jumlah pendengar Radio Prambors Jakarta yang mendengarkan program Sunset Trip yakni sebanyak 365.000 orang. Angka tersebut merupakan akumulasi jumlah pendengar selama tiga bulan, yaitu dari periode April hingga Juni 2020. Data akumulasi tersebut juga menjadi gambaran jumlah pendengar program Sunset Trip dalam setiap bulannya.

Setelah mengetahui jumlah populasi, peneliti kemudian menentukan jumlah sampel yang akan diambil. Untuk mendapatkan seberapa banyak jumlah sampel, peneliti menggunakan rumus Slovin, yaitu rumus untuk menentukan ukuran sampel dari populasi yang diketahui jumlahnya (Purwatiningsih \& Jaya, 2018). Data diperoleh menggunakan kuesioner dengan teknik sampel non probability sampling, yakni teknik pengambilan sampel yang tidak memberi peluang yang sama bagi setiap unsur atau anggota populasi untuk dipilih menjadi anggota sampel.

Peneliti mengambil taraf kesalahan penelitian yang ditolerir sebesar $10 \%$, dengan alasan karena keterbatasan waktu, tenaga, dan biaya yang peneliti miliki. Menurut Philip Sedgwick, 
134 | Kajian Jurnalisme

Volume 05 Nomor 02 Tahun 2022

DOI: $10.24198 / j \mathrm{kj} . v 5 \mathrm{i} 2.32802$

tingkat kepercayaan yang umumnya dapat digunakan dan ditolerir dalam sebuah penelitian terdapat tiga jenis, yakni 99\%, 95\%, dan 90\% (Sedgwick, 2014). Berdasarkan perhitungan sampel menggunakan rumus Slovin dengan taraf kesalahan 10\%, maka didapat hasil jumlah sampel penelitian sebanyak 99,97, atau dibulatkan menjadi 100 orang. Sampel tersebut merupakan pendengar program Sunset Trip di Radio Prambors Jakarta yang berdomisili di Jakarta dan sekitarnya (Bogor, Depok, Tangerang, dan Bekasi) dan berusia 15 sampai dengan 29 tahun yang dinilai dapat mewakili keseluruhan populasi. Responden tersebut kemudian diberikan kuesioner yang berisikan pertanyaan-pertanyaan dari indikator Gratifications Sought dan Gratifications Obtained.

Teknis analisis data yang digunakan yaitu uji wilcoxon untuk melihat signifikan atau tidaknya perbedaan antara Gratifications Sought (GS) dan Gratifications Obtained (GO), lalu membandingkan skor mean antara GS dan GO untuk mengetahui terjadi tidaknya kepuasan melalui kesenjangan kepuasan (discrepancy gratifications). Uji wilcoxon digunakan untuk menegaskan perbedaan yang signifikan dan bukan merupakan suatu kebetulan. Uji wilcoxon digunakan untuk menguji dua variabel yang merupakan dua sampel berkaitan mempunyai distribusi yang sama bila datanya berbentuk ordinal dengan memerhatikan besarnya perbedaan.

Dengan taraf kesalahan sebesar 10 persen, jika sig. (2-tailed) sama atau lebih kecil dari pada 0,1 maka terdapat perbedaan rata-rata yang siginifikan antara Gratifications Sought dan Gratifications Obtained. Namun, Jika sig. (2-tailed) lebih besar dari pada 0,1 maka tidak terdapat perbedaan rata-rata yang signifikan antara Gratifications Sought dan Gratifications Obtained.

Peneliti menggunakan skala Likert sebagai skala pengukuran dalam pengumpulan data. Skala Likert digunakan untuk mengukur sikap, pendapat, persepsi seseorang atau sekelompok orang tentang fenomena sosial. Variabel yang akan diukur dijabarkan menjadi indikator variabel, untuk kemudian dijadikan titik tolak untuk menyusun item-item instrumen berupa pertanyaan atau pernyataan.

Peneliti melakukan pengumpulan data dengan kuesioner kepada sampel penelitian melalui media sosial Twitter, di mana peneliti menggunakan Google Form sebagai medium kuesioner. Metode ini peneliti gunakan karena tingginya aktivitas interaksi yang dilakukan Radio Prambors lewat akun resmi Twitternya dengan para pendengar saat program berlangsung. Terlebih, Radio Prambors juga merupakan radio yang paling sering disebut di media sosial Twitter (Fuadhi \& Ardoyo, 2018).

Dalam mencari hingga mendapatkan populasi sasaran yang menjadi target sampel penelitian, peneliti melakukan pencarian dan penyeleksian dari pendengar-pendengar yang melakukan interaksi berupa cuitan di akun Twitter Prambors selama jam program Sunset Trip berlangsung. Penyeleksian dilakukan peneliti untuk bisa mendapatkan populasi sasaran yang sesuai dengan pembatasan penelitian, yaitu pendengar program Sunset Trip berusia 15-29 tahun yang tinggal di Jakarta, Bogor, Depok, Tangerang, dan Bekasi.

Peneliti melakukan penyebaran kuesioner selama lima hari, dari Senin, 18 Januari 2021 sampai dengan Jum'at, 22 Januari 2021. Penyeleksian dilakukan dengan cara mengirimkan direct message kepada seluruh akun Twitter pendengar yang melakukan interaksi di akun Twitter Prambors untuk mengetahui apakah pendengar tersebut sesuai dengan target sampel peneliti. Ketika sudah diketahui bahwa pendengar sesuai dengan target sampel, maka peneliti akan menyebarkan kuesioner penelitian serta menjelaskannya terlebih dahulu terkait maksudmaksud dari item pernyataan yang ada pada kuesioner tersebut.

Peneliti meneliti seberapa besar motif yang dimiliki pendengar untuk mendengarkan The Highlights berdasarkan motif pengonsumsian media McQuail. Motif yang telah diketahui 
tersebut selanjutnya akan memunculkan kepuasan, di mana peneliti akan mengukur apakah motif-motif yang dimiliki pendengar dapat terpenuhi atau tidak. Kemudian, peneliti akan menganalisis perbandingan mean atau rata-rata skor antara motif dan kepuasan yang didapat untuk mengetahui apakah pendengar terpuaskan atau tidak oleh insert berita The Highlights.

Selama lima hari dari Senin s.d. Jumat, peneliti melakukan seleksi melalui cuitan (tweet) yang diunggah akun Twitter Prambors selama program Sunset Trip berlangsung.

Peneliti menyortir pendengar yang melakukan interaksi (reply tweet) pada cuitan Prambors sesuai dengan target domisili dan usia melalui direct message.

Peneliti memberikan kuesioner kepada khalayak yang sesuai dengan target sampel. Dalam satu harinya, peneliti menargetkan untuk mendapatkan 20 responden.

Setelah mendapatkan target 100 responden, peneliti melakukan olah data. Kemudian, peneliti menganalisis datanya menggunakan teknik uji wilcoxon serta melakukan perbandingan mean skor antara Gratifications Obtained dan Gratifications Sought.

Gambar 1. Alur jalannya penelitian

Sumber: Penelitian lapangan, 2021

\section{HASIL DAN PEMBAHASAN}

Responden dalam penelitian ini merupakan individu berusia 15 sampai 29 tahun yang tinggal di DKI Jakarta dan sekitarnya dan mendengarkan Radio Prambors. Hasil penelitian mendeskripsikan bagaimana profil dari pendengar program Sunset Trip di Radio Prambors Jakarta. Hasil penelitian menunjukkan mayoritas pendengar Radio Prambors Jakarta adalah wanita, dengan responden berjenis kelamin pria berjumlah 25 persen atau 25 orang dan responden berjenis kelamin wanita berjumlah 75 persen atau 75 orang.

Peneliti memfokuskan pada individu yang berada pada generasi milenial (15-34 tahun) sebagai generasi yang paling sering mendengarkan radio. Kemudian, peneliti mempersempit kembali rentang usia sebagai sampel penelitian yakni 15 sampai 29 tahun yang merupakan segmentasi usia pendengar Radio Prambors Jakarta.

Jika dilihat dari hasil penelitian, responden dengan rentang usia 15 sampai 19 tahun berjumlah 28 orang dengan persentase $28 \%$, responden dengan rentang usia 20 sampai 24 tahun berjumlah 62 orang dengan persentase $62 \%$, dan responden dengan rentang usia 25 sampai 29 tahun berjumlah 10 orang dengan persentase 10\%. Maka, pendengar program Sunset Trip didominasi oleh generasi Z. Mengacu pada Badan Pusat Statistik (BPS), generasi Z adalah penduduk yang lahir dalam kurun 1997 sampai 2012. Generasi ini merupakan generasi yang melek dan akrab dengan teknologi, sesuai dengan survei yang dilakukan Populix pada periode Juli hingga September 2020, di mana 68 persen pendengar radio berusia 17 sampai 24 tahun mendengarkan radio melalui gawai pintar (PRSSNI, 2020).

Mayoritas pendengar program Sunset Trip di Radio Prambors Jakarta memiliki latar belakang pendidikan terakhir SMA dan sederajat serta S1. Responden dengan tingkat pendidikan terakhir SMA dan sederajat berjumlah 54 atau 54\%, sementara responden dengan tingkat pendidikan terakhir S1 berjumlah 41 orang atau $41 \%$. 
136 | Kajian Jurnalisme

Volume 05 Nomor 02 Tahun 2022

DOI: $10.24198 / j \mathrm{kj} . v 5 \mathrm{i} 2.32802$

\section{Perilaku Penggunaan Media}

Dalam teori Uses and Gratifications, khalayak dianggap aktif menggunakan media untuk memenuhi kebutuhannya. Berdasarkan asumsi dasar teori ini yang dijelaskan oleh Katz, Blumler, dan Gurevitz, kebutuhan yang terpenuhi akan sangat bergantung pada bagaimana perilaku khalayak dalam menggunakan media (Ardianto et al., 2014).

Maka dari itu, untuk dapat mengetahui perilaku penggunaan media pendengar Sunset Trip, perlu diteliti durasi dan frekuensi mendengarkan program yang bersangkutan, serta frekuensi responden dalam mendengarkan insert The Highlights di program Sunset Trip.

Sebagian besar responden yakni $54 \%$ atau 54 orang mendengarkan program Sunset Trip sebanyak satu sampai dua kali dalam seminggu. Sunset Trip merupakan program prime time sore Radio Prambors Jakarta yang mengudara lima kali dalam seminggu, yakni setiap Senin sampai Jumat. Hal ini menunjukkan bahwa program Sunset Trip belum terlalu diminati oleh para pendengarnya. Salah satu alasannya adalah para penyiar program tersebut tidak "semenghibur" seperti penyiar Prambors pada program prime time pagi.

Berdasarkan durasi mendengarkan atau time spent listening, sebanyak 65 orang atau $65 \%$ mendengarkan program Sunset Trip hanya selama 10 sampai 60 menit dari total durasi empat jam program tersebut. Hal ini mengindikasikan mayoritas pendengar tidak meluangkan waktu yang lama untuk mendengarkan Sunset Trip.

Bahkan, tidak ada satupun responden yang mendengarkan Sunset Trip secara penuh dari awal hingga akhir program. Mengacu pada pembagian segmen radio siaran, program Sunset Trip berada pada segmen afternoon drive, atau sore hari antara jam 15.00 hingga 19.00 atau hingga 20.00. Pembagian waktu pada segmen tersebut mengacu pada pola perilaku pendengar drive time hours, yaitu waktu orang mendengarkan radio saat sedang dalam perjalanan pulang dari kantor menuju rumah. Sehingga, individu yang mendengarkan radio pada jam tersebut tidak memiliki waktu yang cukup lama untuk terus dapat mendengarkan radio (Juniawati, 2015).

Insert berita The Highlights disiarkan pada program Sunset Trip sebanyak empat kali di setiap awal jam, yakni pada 16.00, 17.00, 18.00, dan 19.00. Merujuk pada hasil data tabel sebelumnya di mana mayoritas responden mendengarkan program Sunset Trip sampai 60 menit, pun sejalan dengan mayoritas responden yang mendengarkan insert berita The Highlights tidak lebih dari dua kali pada program tersebut. $71 \%$ responden atau 71 orang mendengarkan insert berita The Highlights hanya satu sampai dua kali.

\section{Motif dalam Mendengarkan The Highlights (Gratifications Sought)}

Tabel 1. Item Pernyataan Gratifications Sought

\begin{tabular}{|c|l|}
\hline No. & \multicolumn{1}{c|}{ Pernyataan } \\
\hline & \multicolumn{1}{c|}{ Motif Informasi } \\
\hline 1. & Saya berharap bisa tahu berita terkini seputar isu nasional \\
\hline 2. & Saya berharap bisa tahu berita terkini dari dunia showbiz \\
\hline 3. & Saya berharap bisa tahu berita terkini dari dunia olahraga \\
\hline 4. & $\begin{array}{l}\text { Saya berharap penyiar beritanya The Highlights bisa membacakan berita dengan jelas dan } \\
\text { gampang buat dipahami }\end{array}$ \\
\hline 5. & Saya berharap bisa dapet berita yang benar-benar valid kebenarannya (sesuai fakta) \\
\hline 6. & Dengan dengerin The Higlights, saya berharap wawasan saya jadi bertambah \\
\hline & \multicolumn{1}{c|}{ Motif Identitas Pribadi } \\
\hline 7. & Saya berharap bisa percaya diri akan luasnya wawasan yang saya punya \\
\hline
\end{tabular}

Kepuasan Khalayak dalam Mendengarkan Insert Berita The Highlights Radio Prambors Jakarta (Wicaksono Tri Kurniawan, Henny Sri Mulyani, dan Muhammad Zen Al-Faqih) 
Volume 05 Nomor 02 Tahun 2022

DOI: $10.24198 /$ jkj.v5i2.32802

\begin{tabular}{|c|l|}
\hline 8. & Saya berharap bisa termotivasi buat selalu ngikutin perkembangan dunia olahraga \\
\hline 9. & $\begin{array}{l}\text { Saya berharap bisa termotivasi buat selalu ngikutin perkembangan artis idola dan film } \\
\text { favorit saya }\end{array}$ \\
\hline 10. & Saya berharap bisa menentukan sikap pro dan kontra saya terhadap isu nasional \\
\hline 11. & $\begin{array}{l}\text { Maya berharap salah satu berita yang disampaikan bisa saya jadikan bahan obrolan dengan } \\
\text { orang terdekat }\end{array}$ \\
\hline 12. & $\begin{array}{l}\text { Saya berharap bisa ikut merasakan apa yang lagi dialami dan dilakukan oleh artis idola } \\
\text { saya }\end{array}$ \\
\hline 13. & $\begin{array}{l}\text { Saya berharap bisa terdorong buat ikut menyumbangkan pendapat dan pandangan saya di } \\
\text { media sosial terhadap isu nasional }\end{array}$ \\
\hline 14. & Saya berharap bisa lebih peka sama apa yang lagi terjadi di lingkungan sekitar \\
\hline 15. & Maya dengerin The Highlights karena ingin dapetin rasa senang. \\
\hline 16. & $\begin{array}{l}\text { Saya dengerin The Highlights karena ingin mengalihkan diri sejenak dari masalah yang } \\
\text { sedang saya alami. }\end{array}$ \\
\hline 17. & Saya dengerin The Highlights karena ingin bersantai dan rileks. \\
\hline 18. & Saya dengerin The Highlights untuk menyalurkan hobi saya mendengarkan radio. \\
\hline 19. & Saya dengerin The Highlights karena ingin rasa bosan saya hilang. \\
\hline
\end{tabular}

Sumber: Kuesioner peneliti, 2021

Menurut McQuail, motif informasi menyangkut kebutuhan akan informasi yang bisa memengaruhi atau membantu seseorang untuk menyelesaikan sesuatu. Ketika mengonsumsi suatu media, khalayak terdorong untuk mencari berita tentang peristiwa ataupun kondisi dari lingkungan terdekatnya, lingkungan masyarakat hingga dunia. Selain itu, informasi juga dicari oleh khalayak untuk bisa memberikan bimbingan yang berkaitan dengan masalah praktis, pendapat, dan saran untuk menentukan pilihan. Pendengar Sunset Trip tentu memiliki harapan yang besar ketika hendak mendengarkan insert berita The Highlights berkaitan dengan kebutuhan informasi mereka.

Sebagian besar pendengar ingin mengetahui berita terkini seputar isu nasional dan showbiz. Salah satu unsur nilai berita adalah kedekatan (proximity). Semakin dekat suatu peristiwa dengan khalayak, maka semakin khalayak terusik dan tertarik. Unsur kedekatan tidak hanya berdasar dari kedekatan geografis, namun juga kedekatan psikologis. Berita tentang showbiz dianggap dekat dengan sebagian besar pendengar yang berusia muda. Pada item nomor 3, 35 persen pendengar menjawab skala netral pada harapan mengetahui berita olahraga. Artinya, sebagian besar pendengar ragu dalam mengharapkan berita olahraga. Item pernyataan nomor 4, 5, dan 6 memperoleh persentase tertinggi pada skala sangat setuju, Oleh sebab itu, pendengar sangat mengharapkan mendapatkan berita yang jelas, mudah dipahami, faktual, dan menambah wawasan. Unsur kejelasan merupakan salah satu ciri utama dari bahasa jurnalistik agar maksud isi berita mudah ditangkap dan tidak kabur.

Motif identitas pribadi ialah harapan untuk memperkuat dan menonjolkan sesuatu yang penting dalam kehidupan atau situasi khalayak. 39 persen pendengar setuju mereka berharap dapat percaya diri akan luasnya wawasan. Pendengar berharap dengan luasnya wawasan yang mereka peroleh dari The Highlights dapat membuat mereka menjadi lebih percaya diri. Keraguan pada harapan mengetahui berita olahraga sejalan dengan sebagian besar pendengar yang juga ragu dalam berharap dapat termotivasi untuk mengikuti perkembangan dunia olahraga. Selanjutnya, sebagian besar pendengar berharap termotivasi mengikuti perkembangan artis 
138 | Kajian Jurnalisme

Volume 05 Nomor 02 Tahun 2022

DOI: $10.24198 / \mathrm{jkj} . v 5 \mathrm{i} 2.32802$

idolanya, sesuai dengan konten utama Prambors yakni konten musik dan hiburan yang berisi informasi selebrita musik dan film. Terakhir, mayoritas pendengar setuju mereka berharap dapat menentukan sikap pro dan kontra terhadap suatu isu nasional.

Motif integrasi dan identitas pribadi menggambarkan harapan khalayak untuk menjadikan media sarana mereka berhubungan dan berinteraksi dengan orang lain. 46 persen responden setuju jika mereka berharap salah satu berita di The Highlights dapat mereka jadikan bahan obrolan dengan orang terdekat. Pada dasarnya, manusia tidak lepas dari berkomunikasi untuk menciptakan dan memupuk hubungan dengan orang lain. Sementara itu, mayoritas pendengar tidak terlalu berharap untuk dapat ikut merasakan apa yang sedang dialami oleh artis idolanya. Dalam The Highlights, berita showbiz yang disiarkan lebih banyak berisi tentang kegiatan atau peristiwa yang baru saja dialami oleh artis. Tabel di atas juga menunjukkan mayoritas pendengar berharap dapat terdorong untuk menyuarakan pendapatnya di media sosial terhadap suatu berita, yang nantinya akan memunculkan interaksi dengan orang lain. Sebagian besar pendengar pun berharap bisa lebih peka terhadap lingkungan sekitarnya.

Indikator terakhir dalam Gratifications Sought yakni motif hiburan, di mana pendengar memiliki harapan untuk mendapatkan hiburan dalam mendengarkan The Highlights. Mayoritas responden menjawab setuju pada seluruh item pernyataan. Artinya, sebagian besar pendengar berharap merasa senang, terlepas dari masalah, rileks dan santai, tersalurkan hobinya, dan hilang rasa bosannya dalam mendengarkan insert berita The Highlights.

\section{Kepuasan Pendengar Usai Mendengarkan The Highlights (Gratifications Obtained)}

Tabel 2. Item Pernyataan Gratifications Obtained

\begin{tabular}{|c|c|}
\hline No. & Pernyataan \\
\hline & Kepuasan Informasi \\
\hline 1. & Habis dengerin The Highlights, saya jadi tahu berita terkini seputar isu nasional \\
\hline 2. & Habis dengerin The Highlights, saya jadi tahu berita terkini dari dunia showbiz \\
\hline 3. & Habis dengerin The Highlights, saya jadi tahu berita terkini dari dunia olahraga \\
\hline 4. & $\begin{array}{l}\text { Saya bisa memahami dengan jelas dan gampang berita yang dibacakan penyiar beritanya } \\
\text { The Highlights }\end{array}$ \\
\hline 5. & $\begin{array}{l}\text { Habis dengerin The Highlights, saya bisa dapet berita yang benar-benar valid } \\
\text { kebenarannya (sesuai fakta) }\end{array}$ \\
\hline \multirow[t]{2}{*}{6.} & Habis dengerin The Highlights, wawasan saya jadi bertambah \\
\hline & Kepuasan Identitas Pribadi \\
\hline 7. & $\begin{array}{l}\text { The Highlights bikin kepercayaan diri saya jadi meningkat karena luasnya wawasan } \\
\text { yang saya punya }\end{array}$ \\
\hline 8. & Saya jadi termotivasi buat selalu ngikutin perkembangan dunia olahraga \\
\hline 9. & Saya jadi termotivasi buat selalu ngikutin perkembangan artis idola dan film favorit saya \\
\hline \multirow[t]{2}{*}{10.} & $\begin{array}{l}\text { Saya bisa menentukan sikap pro kontra saya terhadap isu nasional yang diberitakan di } \\
\text { The Highlights }\end{array}$ \\
\hline & Kepuasan Integrasi dan Interaksi Sosial \\
\hline 11. & Salah satu berita di The Highlights bisa saya jadikan bahan obrolan dengan orang terdekat \\
\hline 12. & $\begin{array}{l}\text { Habis dengerin berita showbiz di The Higlights, saya bisa ikut merasakan apa yang lagi } \\
\text { dialami sang artis }\end{array}$ \\
\hline 13. & $\begin{array}{l}\text { Habis dengerin berita seputar isu nasional di The Highlights, saya bisa nulis pendapat } \\
\text { saya sama isu tersebut di media sosial }\end{array}$ \\
\hline 14. & Saya jadi bisa lebih peka sama apa yang lagi terjadi di lingkungan sekitar \\
\hline
\end{tabular}


Volume 05 Nomor 02 Tahun 2022

DOI: $10.24198 /$ jkj.v5i2.32802

\begin{tabular}{|c|l|}
\hline & \multicolumn{1}{|c|}{ Kepuasan Motif Hiburan } \\
\hline 15. & Saya senang dengan berita-berita yang disampaikan di The Highlights \\
\hline 16. & Waktu luang saya jadi terisi dengan dengerin The Highlights \\
\hline 17 & Dengan dengerin The Highlights, saya bisa menjadi santai dan rileks \\
\hline 18. & Dengan dengerin The Highlights, saya bisa menyalurkan hobi saya mendengarkan radio \\
\hline 19. & Rasa bosan saya hilang dengan dengerin The Highlights \\
\hline
\end{tabular}

Sumber: Kuesioner peneliti, 2021

Berdasarkan pernyataan-pernyataan pada motif informasi, peneliti pun mengajukan enam pernyataan pada indikator kepuasan informasi. Peneliti ingin mengetahui apakah harapan-harapan pada motif informasi yang khalayak miliki dapat terpenuhi setelah mereka mendengarkan insert berita The Highlights. Hasilnya, keenam pernyataan pada kepuasan informasi memperoleh mayoritas jawaban puas dari responden.

Item nomor 1, yaitu kepuasan karena mengetahui berita nasional mendapatkan $49 \%$ jawaban puas, pun dengan item nomor 2 yakni kepuasan karena mengetahui berita showbiz yang memperoleh $53 \%$ jawaban puas. Peneliti mendapat temuan menarik pada item pernyataan nomor 3, yaitu kepuasan dalam mengetahui berita olahraga. Pada motif informasi, mayoritas responden menyatakan netral dalam mengharapkan untuk mengetahui berita olahraga. Namun, terdapat perbedaan terkait apa yang mereka peroleh setelah mendengarkan insert The Highlights, karena 48\% responden menyatakan puas akan berita olahraga yang disiarkan. Artinya, berita olahraga yang disampaikan di The Highlights tetap bisa memuaskan mayoritas khalayaknya walaupun sebelumnya tidak terlalu meminati berita olahraga.

Sebelumnya, item nomor 4, 5, dan 6, yakni kepuasan dalam mendapatkan berita yang jelas, faktual, dan dapat menambah wawasan pada indikator motif informasi sangat diharapkan untuk didapatkan oleh mayoritas responden. Setelah diteliti pada indikator kepuasan informasi, mayoritas responden memilih jawaban puas pada ketiga item tersebut. Item nomor 4 (berita yang jelas dan mudah dipahami) mendapat $51 \%$ jawaban puas dan $38 \%$ sangat puas, item nomor 5 (berita yang faktual) memperoleh $48 \%$ jawaban puas dan 32\% sangat puas, dan item nomor 6 (dapat menambah wawasan) mendapatkan 48\% jawaban puas dan $36 \%$ sangat puas.

Selanjutnya, peneliti meneliti kepuasan yang didapat dari segi identitas pribadi. Dari empat item pernyataan pada indikator kepuasan identitas pribadi, hanya satu item pernyataan yang mendapatkan mayoritas jawaban puas dari responden, yaitu $51 \%$ responden merasa puas karena mereka dapat menentukan sikap pro dan kontra terhadap isu nasional setelah mereka mendengarkan insert berita The Highlights.

Sisanya, item yang berisi pernyataan pendengar menjadi percaya diri akan luasnya wawasan yang didapat memperoleh $45 \%$ jawaban netral, item di mana pendengar menjadi termotivasi untuk mengikuti perkembangan dunia olahraga memperoleh $50 \%$ jawaban netral, dan item yang berisi pernyataan pendengar menjadi termotivasi untuk mengikuti perkembangan artis idola dan film favorit mendapat $38 \%$ jawaban netral. Artinya, mayoritas responden raguragu apakah mereka puas atau tidak terhadap ketiga item tersebut.

Perolehan kepuasan dalam indikator kepuasan integrasi dan interaksi sosial pun tidak sepenuhnya merata. Hal ini ditunjukkan oleh jawaban responden pada empat item pernyataan dalam indikator yang peneliti ajukan kepada responden. Dua item pertanyaan mendapat jawaban puas dari sebagian besar responden, namun dua item sisanya mendapat jawaban netral dari sebagian responden.

Sebanyak 52\% responden merasa puas bahwa salah satu berita di The Highlights dapat mereka jadikan bahan obrolan dengan orang terdekat. Sebagian besar responden sebanyak $49 \%$ 
140 | Kajian Jurnalisme

Volume 05 Nomor 02 Tahun 2022

DOI: $10.24198 / \mathrm{jkj} . v 5 \mathrm{i} 2.32802$

pun menjawab puas bahwa setelah mendengarkan The Highlights mereka menjadi lebih peka terhadap sesuatu yang sedang terjadi di lingkungan sekitar.

Sebanyak 38\% responden merasa ragu-ragu bahwa setelah mendengarkan berita showbiz di The Highlights, responden dapat ikut merasakan apa yang sedang dialami atau dilakukan artis idolanya. Akan tetapi, persentase jawaban netral pada pernyataan tersebut sangat tipis apabila dibandingkan dengan responden yang menjawab puas dengan persentase $35 \%$.

Persentase antara jawaban netral dan puas sangat tipis pada item selanjutnya. Sebanyak $36 \%$ responden menjawab netral, tapi 34\% responden lainnya merasa puas bahwa dengan mendengarkan The Highlights membuat responden ikut menyuarakan pendapatnya tentang isu nasional di media sosial.

Indikator terakhir yang diteliti pada Gratifications Obtained adalah kepuaan hiburan. Melihat dari segi hiburan, ternyata sebagian besar pendengar puas karena mendapatkan hiburan setelah mendengarkan The Highlights. Hal ini ditunjukkan oleh 49 persen responden yang puas karena merasa diri mereka senang setelah mendengarkan insert berita tersebut. 39 persen responden pun puas karena insert berita tersebut dapat mengalihkan mereka sejenak dari masalah pribadi. 50 persen responden puas karena merasa santai dan rileks, 36 persen responden puas karena hobi mendengarkan radio tersalurkan, dan 45 persen responden puas karena rasa bosan mereka hilang.

Setelah hasil penelitian Gratifications Sought dan Gratifications Obtained diketahui, peneliti menguji signifikansi perbandingan rata-rata antara Gratifications Sought dan Gratifications Obtained menggunakan uji wilcoxon melalui aplikasi SPSS Statistics versi 17.0.

Tabel 3. Hasil Uji Wilcoxon

\begin{tabular}{|l|r|}
\hline & Item GO - Item GS \\
\hline$Z$ & $-2.244 \mathrm{a}$ \\
Asymp. Sig. (2-tailed) & .025 \\
\hline
\end{tabular}

Sumber: Hasil Olah Data dengan SPSS Statistics 17.0, 2021

Dari tabel test statistics didapat nilai signifikansi (asymp. Sig. 2-tailed) sebesar 0,025. Jika berdasar pada pengambilan keputusan uji wilcoxon dengan taraf kesalahan 10 persen yaitu 0,1 , maka dapat dinyatakan sig. (2-tailed) $\leq 0,1$. Artinya, terdapat perbedaan rata-rata yang signifikan pada perbandingan antara Gratifications Sought dan Gratifications Obtained dan bukan merupakan suatu kebetulan. Selanjutnya, peneliti melakukan perbandingan mean antara skor masing-masing dari empat indikator Gratifications Sought dan Gratifications Obtained serta mean skor total keduanya untuk mengetahui ada tidaknya kesenjangan kepuasan (discrepancy gratifications).

Tabel 4. Perbandingan Mean Skor Gratifications Sought \& Gratifications Obtained

\begin{tabular}{|c|c|c|c|c|c|}
\hline No. & Indikator GS & Mean Skor & No & Indikator GO & Mean Skor \\
\hline 1. & Motif Informasi & 427,1 & 1. & Kepuasan Informasi & 405,8 \\
\hline 2. & Motif Identitas Pribadi & 374,0 & 2. & Kepuasan Identitas Pribadi & 361,2 \\
\hline 3. & $\begin{array}{l}\text { Motif Integrasi dan } \\
\text { Interaksi Sosial }\end{array}$ & 387,5 & 3. & $\begin{array}{l}\text { Kepuasan Integrasi dan } \\
\text { Interaksi Sosial }\end{array}$ & 385,2 \\
\hline 4. & Motif Hiburan & 397,2 & 4. & Kepuasan Hiburan & 396,2 \\
\hline \multicolumn{2}{|r|}{ Total Mean Skor GS } & 396,4 & \multicolumn{2}{|r|}{ Total Mean Skor GO } & 387,1 \\
\hline
\end{tabular}

Sumber: Hasil Penelitian, 2021 
Berdasarkan indikator discrepancy gratifications, jika mean skor Gratifications Sought lebih besar daripada mean skor Gratifications Obtained, maka pendengar program Sunset Trip di Radio Prambors Jakarta tidak terpuaskan. Sebaliknya, jika mean skor Gratifications Sought lebih kecil atau sama dengan mean skor Gratifications Obtained, maka pendengar program Sunset Trip di Radio Prambors Jakarta telah terpuaskan. Dari hasil tabel di atas, maka dapat dinyatakan total mean skor Gratifications Sought lebih besar daripada total mean skor Gratifications Obtained. Maka dari itu, pendengar program Sunset Trip di Radio Prambors Jakarta tidak terpuaskan oleh insert berita The Highlights.

Hasil perbandingan di atas menunjukkan motif informasi dan motif hiburan merupakan kedua motif yang memperoleh nilai mean skor tertinggi. Motif utama pendengar program Sunset Trip di Radio Prambors Jakarta dalam mendengarkan insert berita The Highlights didorong oleh kebutuhan mereka akan pemenuhan informasi dan pemuas rasa emosionalnya. Menurut McQuail (Jati \& Herlina, 2013), kepuasan informasi timbul dari motif informasi yang menyangkut kebutuhan akan informasi dan bisa memengaruhi atau membantu seseorang untuk menyelesaikan sesuatu.

Pendengar memiliki harapan ketika hendak mendengarkan insert berita The Highlights yang berkaitan dengan kebutuhan informasi. Konsep Gratifications Sought dan Gratifications Obtained merupakan hasil pemikiran dari varian teori Uses and Gratifications, yakni teori nilai pengharapan. Dalam nilai pengharapan, seseorang mengarahkan diri pada suatu media berdasarkan pada kepercayaan dan evaluasi mereka tentang media tersebut. Radio Prambors telah dipercaya berpuluh-puluh tahun oleh para pendengarnya sebagai radio anak muda yang menyajikan hiburan dan informasi yang menarik. Sehingga, kepercayaan tersebut memengaruhi pendengar untuk membentuk harapan dan motifnya pada hiburan dan informasi dalam mendengarkan setiap segmen yang disajikan Prambors.

Dari hasil perbandingan mean skor pula, dapat diketahui tidak ada satupun indikator dari motif pada Gratifications Sought yang dapat terpenuhi pada Gratifications Obtained, dengan kata lain tidak ada satupun indikator kepuasan yang diperoleh pendengar. Pendengar tidak terpuaskan dari segi kebutuhan informasi, karena kepuasan informasi yang diperoleh tidak setinggi yang diharapkan. Terlebih, mayoritas pendengar tidak meminati berita-berita olahraga.

Pendengar juga tidak terpuaskan dari segi kebutuhan identitas pribadi karena mean skor kepuasannya lebih kecil daripada mean skor motifnya, di mana sebagian besar responden merasa ragu apakah mereka telah puas atau tidak dari kebutuhan identitas pribadinya. Kepuasan identitas pribadi dipengaruhi oleh sejauh mana seseorang dapat memperkuat dan menonjolkan sesuatu atau situasi yang penting dalam nilai dirinya setelah mengonsumsi suatu media (Jati \& Herlina, 2013). Dari data yang peneliti dapatkan, tidak ada satupun aspek atau kategori dalam insert berita The Highlights yang dapat memperkuat nilai dirinya.

Kepuasan integrasi dan interaksi sosial pun tidak terpenuhi dari penghitungan akumulasi skor, walaupun perbedaan mean skor dengan motifnya cukup tipis. Dalam hasil penelitian kepuasan integrasi dan interaksi sosial, ada dua item yang kepuasannya dapat terpenuhi, yakni pendengar puas akan berita di The Highlights yang dapat dijadikan bahan obrolan atau interaksi dengan orang terdekat, dan pendengar merasa puas bahwa mereka dapat lebih peka terhadap apa yang terjadi di lingkungan sekitar.

Model yang ada pada Uses and Gratifications membahas motif-motif dan alternatif fungsional untuk memenuhi kebutuhan khalayak. Salah satu contohnya adalah sebagai manusia, setiap individu pasti memiliki kebutuhan dasar untuk melakukan interaksi sosial. Penggunaan media dapat menjadi alternatif fungsional bagi interaksi yang sesungguhnya untuk dapat memenuhi kebutuhan setiap individu dalam mengadakan interaksi sosial (Ardianto et al., 
142 | Kajian Jurnalisme

Volume 05 Nomor 02 Tahun 2022

DOI: $10.24198 / j \mathrm{kj} . v 5 \mathrm{i} 2.32802$

2014).

Hal tersebut membuktikan bahwa pengonsumsian media tidak pernah lepas dari fungsinya untuk dapat memenuhi kebutuhan khalayak dalam berinteraksi. Termasuk bagi pendengar Sunset Trip yang juga merasa kebutuhan interaksionalnya terpenuhi setelah mendengarkan berita-berita di The Highlights.

Dari segi hiburan, pendengar pun tidak mengalami kepuasan. Walaupun sebagian besar responden menjawab puas pada seluruh item pernyataan kepuasan hiburan, tetapi kepuasan yang mereka dapat tidak sebanding dengan tingginya harapan yang mereka miliki pada motif hiburan.

Uses and Gratifications meneliti asal mula kebutuhan manusia secara psikologis dan sosial yang menimbulkan harapan atau motivasi dalam menggunakan suatu media tertentu. Motivasi dibentuk dari elemen-elemen psikologis yang salah satunya meliput suasana hati seseorang. Sehingga, nilai hiburan menjadi nilai yang seringkali dicari banyak orang ketika mengonsumsi suatu media (Ardianto et al., 2014).

Dalam teori Uses and Gratifications (Novanry, 2015), kebutuhan-kebutuhan yang dimiliki individual akan memunculkan motif-motif seseorang untuk memenuhi kebutuhan tersebut melalui pengonsumsian media yang disebut dengan Gratifications Sought atau kepuasan yang dicari. Dengan adanya motif yang terpenuhi atau tidak terpenuhi akan memengaruhi sikap dan perilaku seseorang dalam mengonsumsi media tersebut dalam rangka pemenuhan kebutuhannya. Tidak adanya motif pendengar Sunset Trip yang dapat terpenuhi memengaruhi sikap pendengar Sunset Trip terhadap pengonsumsian insert berita The Highlights. Hal ini ditunjukkan pada perilaku penggunaan media oleh pendengar program Sunset Trip Radio Prambors Jakarta dimana frekuensi mendengarkan The Highlights dalam seharinya tergolong rendah.

\section{SIMPULAN}

Hasil penelitian menunjukkan motif informasi merupakan harapan pendengar yang paling utama dalam mendengarkan insert berita The Highlights. Tujuan utama pendengar adalah untuk mengetahui berita terkini dari isu nasional dan showbiz secara jelas serta mudah dipahami dan valid serta untuk memperkaya wawasan mereka. Namun, kepuasan nyata informasi yang mereka peroleh tidak sebesar harapan informasi dimilikinya. Motif hiburan menjadi harapan kedua yang paling banyak dimiliki pendengar. Selain mencari informasi, tujuan pendengar mendengarkan The Highlights juga untuk dapat merasa senang, teralihkan masalah pribadinya, merasa rileks dan santai, menghilangkan bosan, dan tersalurkan hobinya. Walaupun sebagian besar pendengar merasa puas, namun kepuasan dari motif hiburan tidak dapat terpenuhi karena mean skor kepuasannya lebih sedikit ketimbang mean skor motifnya.

Penelitian ini juga menunjukkan jika perilaku konsumsi pendengar Radio Prambors Jakarta baik itu frekuensi dan durasi dalam mendengarkan program Sunset Trip maupun insert berita The Higlights pada program tersebut tergolong rendah. Dari kesimpulan tersebut, maka peneliti memiliki saran kepada tim program Sunset Trip agar meningkatkan kualitas insert berita The Highlights, baik dari segi pemilihan berita, penulisan bahasa jurnalistik, sampai penyajian dan pembawaan berita oleh penyiar The Highlights. Terlebih dalam pertimbangan pemilihan berita, mengingat mayoritas pendengar yang berjenis kelamin wanita tidak terlalu meminati berita olahraga. Selain itu, peneliti juga berharap tim program Sunset Trip dapat meningkatkan kualitas siaran programnya secara keseluruhan, agar dapat meningkatkan minat dengar pendengar terhadap program Sunset Trip. Dikarenakan penelitian ini hanya terbatas dilakukan di populasi satu program prime time Radio Prambors Jakarta, maka penelitian 
selanjutnya perlu melibatkan program prime time Prambors yang lain agar hasil kepuasan pendengar terhadap insert berita The Highlights bisa diperoleh secara lebih menyeluruh. Selain itu, penelitian selanjutnya juga perlu untuk mengembangkan indikator-indikator lainnya dalam mencari tahu kepuasan khalayak dalam konten siaran kilas berita di suatu radio.

\section{DAFTAR PUSTAKA}

Ardianto, E., Komala, L., \& Karlinah, S. (2014). Komunikasi massa: Suatu pengantar. Bandung: Simbiosa Rekatama Media.

Christina, E. L. (2013). Kepuasan pendengar terhadap program Sonora News di radio Sonora Surabaya. Jurnal E-Komunikasi, 1(1), 1-11. Diakses dari https://publication.petra.ac.id/ index.php/ilmu-komunikasi/article/view/94

Fuadhi, A., \& Ardoyo, N. A. W. (2018). Pengaruh program Sunset Trip di radio Prambors terhadap minat mendengar program tersebut. Jurnal Pantarei, 2(2), 1-7. Diakses dari https://jom.fikom.budiluhur.ac.id/index.php/Pantarei/article/view/116

Gumilar, G., \& Zulfan, I. (2014). Penggunaan media massa dan internet sebagai sarana penyampaian informasi dan promosi oleh pengelola industri kecil dan menengah di Bandung. Jurnal Kajian Komunikasi, 2(1), 85-92. https://doi.org/10.24198/jkk.v2i1.6054

Jati, R. P., \& Herlina, M. (2013). Hubungan antara radio Streaming dengan persepsi dan kepuasan audiens di PT MNC Skyvision Jakarta. Jurnal ASPIKOM, 2(1), 589-602. https://doi.org/10.24329/aspikom.v2i1.37

Juniawati, J. (2015). Urgensi program siaran pada lembaga penyelenggara penyiaran. Jurnal Al-Hikmah, 9(2), 146-158. https://doi.org/10.24260/al-hikmah.v9i2.321

Kementerian Komunikasi dan Informatika. (2016). Praktisi radio siaran perlu sikapi era digital dan MEA. Diakses dari Kominfo website: https://www.kominfo.go.id/content/ detail/6619/praktisi-radio-siaran-perlu-sikapi-era-digital-dan-mea/0/berita_satker

Komisi Penyiaran Indonesia. (2018). Radio tetap eksis di era internet. Diakses dari KPI website: http://www.kpi.go.id/index.php/id/umum/38-dalam-negeri/34249-radio-tetap-eksis-diera-internet

Kusnandar, V. B. (2019). Hanya 13\% masyarakat yang masih mendengarkan radio. Diakses dari Databoks website: https:/databoks.katadata.co.id/datapublish/2019/10/23/hanya13-persen-masyarakat-yang-masih-mendengarkan-radio

Media Indonesia. (2021). Tampil adaptif di industri kreatif jadi kunci sukses Prambors. Diakses dari mediaindonesia.com website: https://mediaindonesia.com/hiburan/391291/tampiladaptif-di-industri-kreatif-jadi-kunci-sukses-prambors

Novanry, R. (2015). Kepuasan khalayak terhadap isi berita tabloid Otomotif. WACANA: Jurnal Ilmiah Ilmu Komunikasi, 14(2), 110-200. Diakses dari https://journal.moestopo.ac.id/ index.php/wacana/article/view/107

Pavitasari, S. P., Fadilah, E., \& Merdekawati, I. (2019). Persepsi khalayak terhadap radio komunitas kampus 107.8 Mandalla FM. Jurnal Kajian Jurnalisme, 3(1), 95-106. https:// doi.org/10.24198/jkj.v3i1.22451

PRSSNI. (2020). Apakah pandemi mempengaruhi consumption di Indonesia? Diakses dari radioindonesia.co.id website: https://radioindonesia.co.id/news-detail/apakah-pandemimempengaruhi-consumption-di-indonesia

Purwatiningsih, S. D., \& Jaya, S. (2018). Efektitivitas iklan layanan masyarakat tentang "Mengendarai sepeda motor di usia bawah umur" di radio Prambors FM Jakarta. Jurnal Ikom Usni, 7(2), 90-110. Diakses dari https://isip.usni.ac.id/readjurnal/12/JURNALIKOM 
144 | Kajian Jurnalisme

Volume 05 Nomor 02 Tahun 2022

DOI: $10.24198 /$ jkj.v5i2.32802

Sedgwick, P. (2014). Understanding confidence intervals. BMJ, 349(October 2014), 5-7. https://doi.org/10.1136/bmj.g6051

Setyowati, R. I., Sudaryanto, E., \& Satvikadewi, A. P. (2015). Efek dan kebiasaan mendengarkan siaran radio melalui mobile application: Studi deskriptif pada Komunitas She and Friends. Jurnal Representamen, 1(1), 1-9. Diakses dari http://jurnal.untag-sby.ac.id/index.php/ representamen/article/view/1443

Siradj, N. T., \& Hidayat, R. (2018). Pengaruh konten radio terhadap keputusan mendengarkan radio (Studi kasus pada radio Play99ers 100 FM Bandung). EProceedings of Applied Science, 4(3), 1129-1137. Diakses dari https://openlibrarypublications.telkomuniversity. ac.id/index.php/appliedscience/article/view/7122

Syukro, R. (2019). Meskipun platform digital tumbuh, radio masih digemari. Diakses dari Berita Satu website: https://www.beritasatu.com/hiburan/591775/meskipun-platformdigital-tumbuh-radio-masih-digemari 